\title{
Extract of Moringa Root Inhibits PMA-induced Invasion of Breast Cancer Cells
}

\author{
Hyun-Ji Cho ${ }^{1,2}$ and Young-Chae Chang ${ }^{1,2}$ * \\ ${ }^{1}$ Research Institute of Biomedical Engineering and ${ }^{2}$ Department of Medicine, Catholic University of Daegu School of Medicine, Daegu 705-718, \\ Korea
}

Received October 24, 2013 /Revised November 28, 2013 / Accepted January 23, 2014

\begin{abstract}
The moringa (Moringa deifera Lam.) plant is used as food and as an anti-allergic agent. In this study, we studied the inhibitory effect of moringa root extract on the expression of PMA-induced matrix metalloproteinase-9 (MMP-9), which is the main factor implicated in the invasion and metastasis of cancer cells in MCF-7 cells. At first, various moringa extracts were examined in the MCF-7 cells. Both moringa root extract and leaf extracts inhibited PMA-induced MMP-9 activity, but the root extract suppressed PMA-induced MMP-9 activity to a greater extent than the leaf extract. The moringa root extract also inhibited PMA-induced MMP-9 protein expression and cell invasion. According to RT-PCR, the treatment of the MCF-7 cells with moringa root extract decreased levels of PMA-induced MMP-9 mRNA expression, but not the expression of TIMP-1 and -2, indicating that moringa root extract prevents the transcription of MMP-9 in response to PMA. In addition, moringa root extract specifically suppressed the phosphorylation of ERK/JNK, but not p38. We suggest that moringa root extract abolishes MMP-9 activity/expression through ERK/JNK. In conclusion, moringa root extract suppressed PMA-induced MMP-9 activity/expression by inhibiting the phosphorylation of ERK/JNK in MCF-7 cells. These results indicate that moringa root extract may be a potential antimetastatic and anti-invasive agent. Future clinical research is needed on the anticancer properties of moringa root extract.
\end{abstract}

Key words : MAP kinase, matrix metalloproteinase-9 (MMP-9), moringa, tumor invasion

\section{서 론}

암은 인간의 사망원인 중 많은 부분을 차지하며, 그 중 유방 암은 암의 전이에 따라 생존율이 비례한다[24]. 암은 전이를 통해 다른 기관으로 옮겨가며, 부착, 침윤, 이동 등의 단계를 거쳐 이루어진다. 암세포가 다른 조직으로 전이되기 위해서는 세포외기질(extracellular matrix)의 분해가 필수적으로 요구 되며[30], 세포외기질 분해에 주요하게 작용하는 인자로 단백 질 분해효소인 matrix metalloproteinase (MMPs)가 있다[7, 17]. MMPs는 아연/칼슘 의존성으로서 30 종류가 알려져 있으 며, 기질의 종류에 따라 구분된다. 대부분 암세포 침투와 전이 에 작용하며, 세포 성장 및 형태형성과 세포사멸에 관련되어 있는 것으로 알려져 있다[12, 23]. MMPs 가운데 matrixmetalloproteinase-9 (MMP-9, gelatinase B)은 세포의 기저 막을 구성하는 type IV collagenase과 fibronectin을 분해하여 암세포의 침투와 전이를 용이하게 하는 작용 한다[6]. 특히

\footnotetext{
*Corresponding author

Tel : +82-53-650-4848, Fax : +82-53-650-4849

E-mail : ycchang@cu.ac.kr

This is an Open-Access article distributed under the terms of the Creative Commons Attribution Non-Commercial License (http://creativecommons.org/licenses/by-nc/3.0) which permits unrestricted non-commercial use, distribution, and reproduction in any medium, provided the original work is properly cited.
}

MMP-9은 유방암에서 높은 발현을 나타내는 것으로 알려져 있다[29]. 유방암 세포주인 MCF-7세포에서 MMP-9 유전자가 변이한 경우 종양과 관련된 신생혈관생성이 감소하여 암세포 전이가 저해된다[4]. 반대로, 혈청에 MMP-9의 수치가 증가하 는 경우 유방암환자의 생존률이 낮으며, 그 예후도 좋지 않은 것으로 확인되었다[26, 28]. 이처럼, MMP-9의 발현 및 활성은 유방암 전이 및 성장에 주요한 인자임을 알 수 있다.

$\mathrm{MMP}-9$ 은 다양한 성장인자[20]와 염증관련 사이토카인 [31], 12-O-tetradecanoylphorbol-13-acetate (PMA)[7]에 의해 발현이 유도되며, 세포 내 자연적으로 발생된 내생적 억제인 자인 tissue inhibitor of metalloproteinase-1 (TIMP-1)에 의해 그 발현 및 활성이 조절된다[27]. 특히, MMP-9 활성 유도 인자 인 PMA는 protein kinase C (PKC), mitogen-activated protein kinase (MAPKs), and phosphoatidylinositol 3-kinase (PI3K)/Akt signaling pathways를 통하여 activator protein-1 $(\mathrm{AP}-1)$ 과 nuclear factor-kappaB $(\mathrm{NF}-\mathrm{kB})$ 같은 전사인자의 활 성을 유도함으로써 MMP-9 발현을 조절한다[11, 15].

모링가의 학명은 Moringa oleifera Lam.으로 드럼스틱 또는 고추냉이 나무로 알려져 있으며, 동남아시아와 극동지방, 아 프리카 등 세계 여러 나라에 널리 펴져 있다[19]. 전통적으로 모링가의 모든 부위는 종양, 히스테리, 괴혈병, 마비성발작, 피부감염과 같은 질환에 포괄적으로 사용되었다[24]. 모링가 의 꽃, 뿌리, 씨, 잎, 열매에는 다른 식물들에 비해 비타민, 플라 보노이드, 아미노산 등과 같은 피토케미칼(phytochemical)이 
풍부한 것으로 확인되었다[2]. 특히, 모링가 잎은 콜레스테롤 제거 및 간손상 방지와 염증, 심장병 등을 치료하는 효과가 있으며 $[10,18]$, 뿌리와 꼬투리, 씨, 나무진액은 관절염 치료에 효과가 있는 것으로 알려져 있다[1,16].

이처럼 모링가의 모든 부위가 다양한 질환을 치료하는 것으 로 확인되었으나 암 전이의 저해 효과에 대한 연구는 아직 미흡한 실정이다. 따라서 이 연구에서는 대표적으로 모링가 씨, 뿌리, 잎, 열매 추출물질을 이용하여 유방암 세포의 침투와 전이에 중요하게 작용하는 MMP-9의 활성 및 발현조절에 미 치는 영향을 확인하고 작용기전을 연구하였다.

\section{재료 및 방법}

\section{모링가 추출물 제조}

본 실험에 사용한 모링가는 스리랑카에서 구입하여 부위별 로 분말화 된 시료를 주식회사 유림물산(대구시 달서구 월암 동 1-83)에서 제공받아 사용하였다. 시료 무게의 10 배(w/v)의 $80 \%$ 메탄올에 가하여 24 시간 동안 정치하여 총 3 회 반복 추출하였다. 추출액을 여과하여 rotary vacuum evaporator (R- 3000, Büchì Switzerland)로 $55^{\circ} \mathrm{C}$ 에서 농축한 다음 건조하 여 실험에 사용하였다.

\section{세포배양}

실험에 사용한 유방암세포주인 MCF-7과 MDA-MB-231세 포는 American type culture collection (Manassas, VA, USA) 에서 구입하여 사용하였으며 $10 \%$ 혈청(fetal bovine serum; FBS) (Invitrogen Co., Grand Island, NY, USA)과 1\% 항생 제 (antibiotic/antimycotic) (Invitrogen)를 첨가한 Dulbecco's modified Eagle's medium (DMEM, Invitrogen)을 사용하여 $5 \% \mathrm{CO}_{2}, 37^{\circ} \mathrm{C}$ 조건에서 배양하였다.

\section{Gelatin zymography 분석을 이용한 MMP 활성 확인}

6 well plate에 $10 \%$ FBS가 첨가된 배지를 이용하여 세포를 $1 \times 10^{6}$ cells/well의 농도로 24 시간 동안 부착시킨 후 혈청이 없는 배지로 교환 후 모링가 추출물과 PMA를 처리하였다. 24 시간 후 배지를 취하여, $0.1 \%$ gelatin을 포함한 SDS-polyacrylamide gel에 전기영동 하였다. 전기영동 후 gel을 $2.5 \%$ triton X-100 용액에서 30 분 동안 처리한 다음, $10 \mathrm{mM} \mathrm{CaCl}$, $0.01 \% \mathrm{NaN}_{3}$ 와 $50 \mathrm{mM}$ Tris- $\mathrm{HCl}$ ( $\mathrm{pH}$ 7.5)가 함유된 buffer를 처리하여 $37^{\circ} \mathrm{C}$ incubator에서 24 시간 동안 반응시켰다. 반응 후 gel을 $0.2 \%$ coomassie brilliant blue 용액으로 염색한 다음 탈색하여 MMP-9의 활성 정도를 확인하였다.

\section{Western blot을 이용한 염증관련 단백질의 발현 측정}

세포를 $60 \mathrm{~mm}$ culture dish에 $2 \times 10^{6}$ cells/well이 되도록 분주하여 부착시킨 다음 모링가 추출물과 $\mathrm{PMA}$ 를 처리하여
24 시간 배양하였다. 배양된 세포를 회수하여 lysis buffer (50 $\mathrm{mM}$ Tris, $150 \mathrm{mM} \mathrm{NaCl}, 5 \mathrm{mM}$ EDTA, 0.5\% NP-40, $100 \mathrm{mM}$ PMSF, $1 \mu \mathrm{g} / \mathrm{ml}$ leupeptin, $1 \mu \mathrm{g} / \mathrm{ml}$ aprotinin)를 넣고 $4^{\circ} \mathrm{C}$ 에 서 30 분간 처리하여 단백질을 추출하였다. $12,000 \mathrm{rpm}$ 으로 5 분간 원심분리 하여 상층액을 얻은 다음 Bradford assay (Bio-rad, Hercules, CA, USA)를 이용하여 추출된 단백질을 정량 하였다. 정량 된 단백질을 SDS-polyacrylamide gel에 전 기영동하고 Immobilon-P-membrane (Millipore, Billerica, $\mathrm{USA}$ )에 그 단백질을 흡착시켰다. 실험에 사용한 MMP-9과 $\beta$-actin 항체는 Santa Cruz Biotechnology (Santa Cruz, CA, USA)에서 구입하여 사용하였다. 탐색하고자 하는 단백질의 1 차 항체와 2차 항체를 반응 시킨 후 ECL kit (Amersham Pharmacia, Buckinghamshire, England)을 사용하여 X-ray film에 노출시켜 단백질 발현 정도를 확인하였다.

RNA 분리 및 reverse transcription-polymerase chain reaction (RT-PCR)

6 well plate에 $10 \% \mathrm{FBS}$ 가 첨가된 배지를 이용하여 세포를 $2 \times 10^{6}$ cells/well의 농도로 부착시킨 후 혈청이 없는 배지로 갈아준 다음 모링가 추출물과 TNF- $a$ 를 처리하였다. 처리 12 시간 후 세포를 회수하여 Trizol reagent (Molecular Research center, Inc., NY, USA)를 사용하여 RNA를 분리하였다. 분리 된 RNA는 spectrophotometer와 $1 \%$ agarose gel에 전기영동 하여 분리된 RNA를 정량, 확인하였다. 확인된 RNA $1 \mu \mathrm{g}$ 과 oligo DT (100 pM) 1 l, 역전사 효소 (Promega, Madison, $\mathrm{WI}, \mathrm{USA}$ )를 포함하여 총량이 $20 \mathrm{\mu l}$ 되도록 $\mathrm{DEPC}$ 를 첨가하여 합성한 cDNA에 $2.5 \mu \mathrm{g}$ mix buffer (10X PCR buffer, $50 \mathrm{mM}$ $\mathrm{MgCl}_{2} 10 \mathrm{mM}$ dNTP mix, DEPC)와 sense, antisense primer (MMP-9: sense: 5'-CACTGTCCACCCCTCAGAGC-3', antisense: 5'-GCCACTTGTCGGCGATAAGG-3'; TIMP-1: sense: 5'-CTGTTGTTGCTGTGGCTGATA-3', antisense: 5'-CCGTCCACAAGCAATGAGT-3'; TIMP-2: sense: 5'-GTAGTGATCAGGGCCAAAG-3', antisense: $5^{\prime}$-TTCTCTGTGACCCAGTCCAT-3'; $\beta$-actin: sense: 5'- AGGGTGTGATGGTGGGTATGGG-3' antisense: $5^{\prime}$ - CAGGATCTTCATGAGGTAGTC-3') 를 혼합한 후 $\mathrm{PCR}$ 기기를 이용하여 $\mathrm{DNA}$ 를 증폭시킨 다음 ethidium bromide가 첨가된 1\% agarose gel로 전기영동을 실 시하여 분석하였다.

\section{Invasion 분석}

24 well trans-well chamber의 filter 바닥에 $0.5 \mathrm{mg} / \mathrm{ml}$ 농도 의 matrigel을 $25 \mu 1$ 로 코팅하였다. Chamber 바깥쪽 바닥에는 세포가 배양된 배양액 $500 \mu \mathrm{l}$ 를 넣고, 안쪽에는 세포 (5× $10^{4} /$ well) $200 \mu 1$ 와 모링가 추출물 또는 PMA를 혼합하여 분주 하였다. $5 \% \mathrm{CO}_{2}, 37^{\circ} \mathrm{C}$ 에서 24 시간 동안 배양한 다음, 메탄올 로 1 분간 고정시킨 후 hematoxylin과 eosin으로 세포막과 핵 
을 염색하였다. Filter의 안쪽 부분은 면봉을 이용하여 불필요 한 세포를 제거하고 filter를 잘라내어 xylene에 넣어 불순물을 제거하여 slide glass에 놓고 고정액을 떨어뜨린 후 cover glass 를 덮어 현미경으로 관찰하였다.

\section{통계처리 분석}

실험 결과의 통계적 처리는 student's $t$ test 및 analysis of variance (ANOVA)로 하였으며, $p<0.05$ 를 유의한 차이의 한계 로 하였고, 실험결과의 표현은 means $\pm S$.E로 하였다.

\section{결과 및 고찰}

모링가 추출물에 의한 MMP-9 활성 및 발현 조절 효과 확인 다양한 암에서 발생되고 암 발병 시 나뺀 예후를 유도하는 대표적인 인자로 MMP-9을 제시할 수 있으며[21], 이는 암세 포 전이에 주요하게 작용하는 활성 인자로도 알려져 있다[7]. 따라서 모링가 추출물에 의한 MMP-9 활성 저해 정도를 확인 하기 위해 zymography assay를 수행하였다. MCF-7 세포에 MMP-9 유도물질인 PMA 처리 후 모링가 추출물을 부위별로 처리한 결과 4 가지 부위 중 뿌리와 잎 추출물에 의해 MMP-9 활성이 농도 의존적으로 저해되었다. 또한 뿌리와 잎 추출물 중 뿌리 추출물 $200 \mu \mathrm{g} / \mathrm{ml}$ 처리조건에서 MMP-9 활성이 가장 많이 감소하는 것으로 확인 되었다(Fig. 1). 이 결과로 모링가 부위별 추출물에 따라 그 효과가 다르게 나타나는 것으로 예 상된다. 또한 최근 발표된 연구결과에 따르면 모링가 과실 추 출물이 LPS 처리에 따른 NO/iNOS의 발현을 저해하고[13], 모링가 잎 추출물은 암세포 증식을 억제한다는 연구결과가 발표되어[25] 부위별 추출물에 따른 다른 효과 양상이 뒷받침 된다.

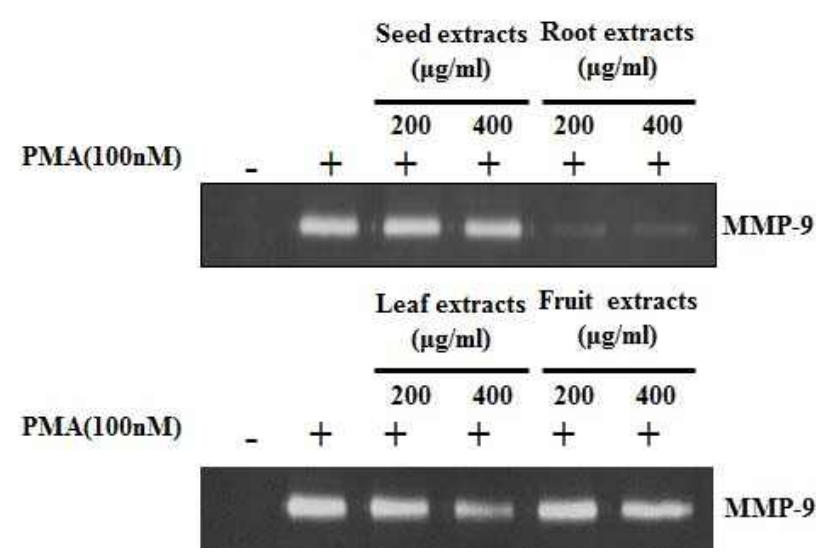

Fig. 1. Effect of extracts from different parts of moringa on PMA-induced MMP-9 activity in MCF-7 cells. MCF-7 cells were treated with the indicated concentrations of moringa extracts and PMA for $24 \mathrm{hr}$. The conditioned medium was prepared and used for gelatin zymography.
그리고 이 결과를 재확인 하고자 몇 가지 유방암 세포주를 사용하여 실험을 수행하였다. MCF-7과 MDA-MB-231 유방암 세포에 각각 모링가 뿌리 추출물을 다양한 농도로 처리하여 비교한 결과 MCF-7과 MDA-MB-231 세포 모두 모링가 뿌리 추출물에 농도 의존적으로 MMP-9 활성이 감소되어 모링가 뿌리 추출물의 MMP-9 억제 효과가 세포 비특이적인 것으로 확인되었다(Fig. 2A). 또한 western blot을 이용한 단백질 발현 실험에서 모링가 뿌리 추출물에 농도 의존적으로 MCF-7 세포 의 MMP-9 발현이 저해되어(Fig. 2B) 이 결과들로 모링가 추출 물 중 뿌리 추출물이 MMP-9 활성 및 발현을 가장 효과적으로 저해시키는 것으로 확인되었다.

\section{모링가 뿌리 추출물에 의한 암 세포 침투 억제효과}

MMP-9은 유방암을 비롯하여 전립선암, 피부암 등의 암세 포 침투와 전이에 주요하게 작용하는 인자이며, in vitro와 in vivo 실험에서도 anti-sense MMP-9 처리에 의해 암세포의 침 투가 저해된다[9]. 따라서 이 실험에는 모링가 뿌리 추출물의 MMP-9 활성 억제를 통한 암세포 침투와 전이의 저해 효과를 확인하기 위해 cell invasion assay를 수행하였다. PMA 처리 에 의해 증가된 암세포 침투가 모링가 뿌리 추출물 $200 \mathrm{\mu g} / \mathrm{ml}$ 처리에 의해 침투율이 $50 \%$ 이상 감소되었다(Fig. 3). 이 결과로 모링가 뿌리 추출물이 MMP-9 활성 및 발현 억제를 통해 유방 암 세포의 침투 저해에 작용하는 것으로 예상된다.
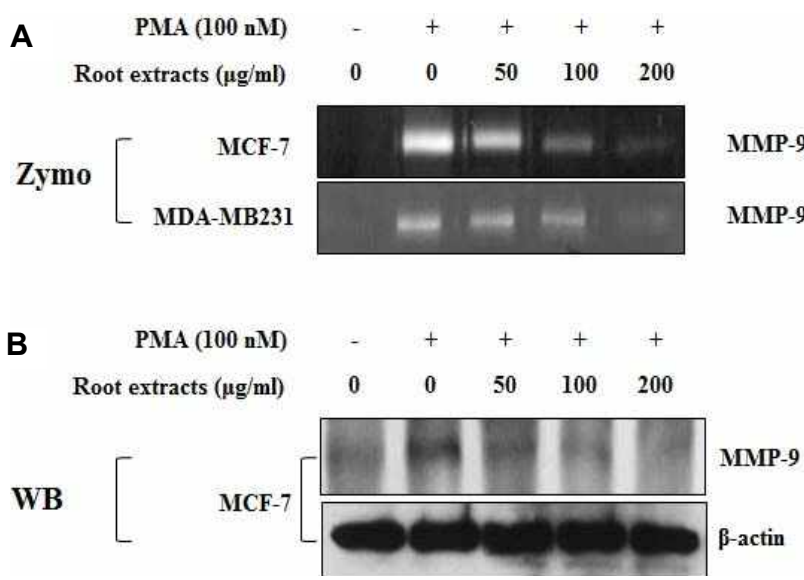

Fig. 2. Inhibitory effect of moringa root extract on PMA-induced MMP-9 activity and expression in cancer cells. (A) MCF-7 cells and MDA-MB-231 cells were treated with the indicated concentrations of moringa root extract and PMA for $24 \mathrm{hr}$. The conditioned medium was prepared and used for gelatin zymography. (B) Moringa root extract was added into MCF-7 cells for $1 \mathrm{hr}$ before PMA stimulation and protein samples were incubated for 24 hr after PMA stimulation. The protein levels of MMP-9 were evaluated by Western blot analysis. $\beta$-actin was used as an internal control. 

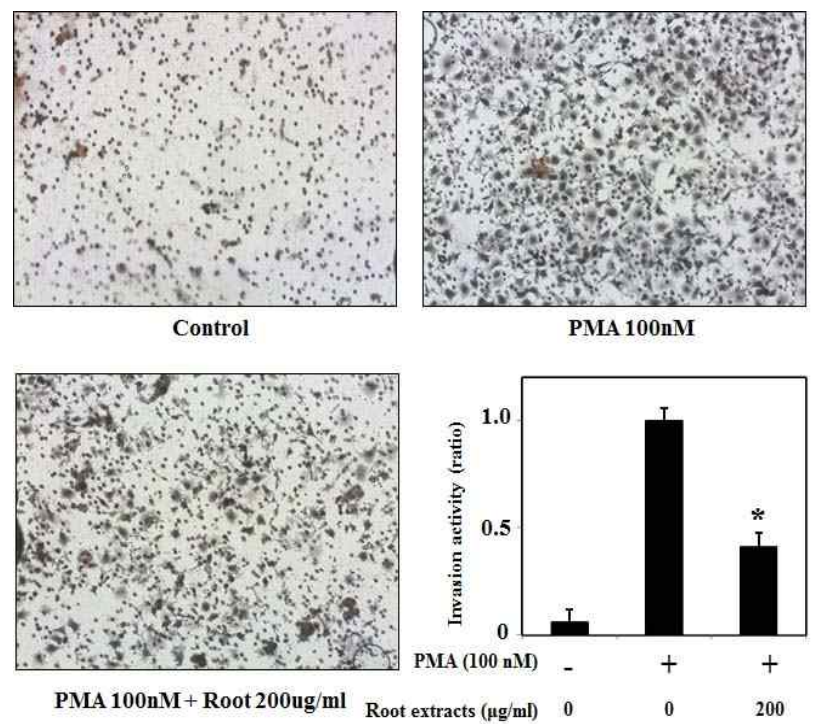

Fig. 3. Inhibitory effect of moringa root extract on PMA-induced cell invasion in MCF-7 cells. $5 \times 10^{5}$ MCF-7 cells were seeded in the chamber. The cells were plated on the Matrigel-coated the upper chamber. The lower chamber was filled DMEM with various concentrations of moringa root extract. Cells in the chamber were incubated for $24 \mathrm{hr}$ at $37^{\circ} \mathrm{C}$ and cells that had invaded the lower surface of the membrane were fixed with methanol and stained with hematoxylin and eosin. Random fields were counted by light microscopy under a high power field.

모링가 뿌리 추출물에 의한 MMP-9과 TIMPs의 mRNA level 조절 확인

MMP-9은 암세포에서 세포 내에 존재하는 내생적 억제인 자인 TIMP-1과 -2에 의해 발현 및 활성이 조절되는 것으로 알려져 있다[27]. 이에 실험에서는 모링가 뿌리 추출물에 의한 작용인자를 확인하기 위해 MMP-9과 TIMP-1과 -2의 mRNA 발현을 확인 하였다. 그 결과 모링가 뿌리 추출물에 농도의존 적으로 $\mathrm{MMP}-9$ 의 mRNA 발현이 억제됨을 확인 할 수 있으며, TIMP-1과 -2는 모링가 뿌리 추출물에 의해 발현이 저해되지 않는 것으로 확인되었다(Fig. 4). 앞서 발표된 연구결과에서도 TIMP-1과 -2의 발현에는 영향 없이 MMP-9의 전사조절을 통 하여 MMP-9 단백질 발현 및 활성을 저해한다는 것이 확인되 었다[7]. 따라서 이 결과로 모링가 뿌리 추출물이 TIMP-1과 -2의 발현유도를 통해 간접적으로 MMP-9 활성 및 발현을 조 절하는 것이 아니라 직접적으로 MMP-9 전사억제를 통하여 단백질 발현조절에 작용함을 예상할 수 있다.

\section{모링가 뿌리 추출물의 MAP kinase 활성 조절}

MMP-9은 암세포의 종류와 MMP-9 활성을 유도하는 다양 한 성장인자 및 사이토카인에 따라 PI3K/Akt와 MAP kinas 등 다양한 기전을 통해 조절된다[11]. 그 중에서도 대표적으로 $\mathrm{PMA}$ 처리에 의해 증가된 MMP-9의 활성 및 발현을 조절하는

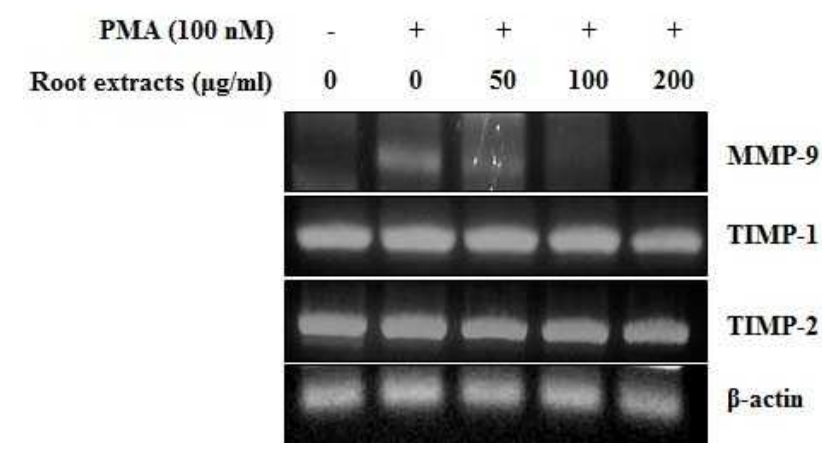

Fig. 4. Inhibitory effect of moringa root extract on mRNA expression of PMA-induced MMP-9 and TIMPs in MCF-7 cells. MCF-7 cells were treated with the indicated moringa root extract in the presence of PMA for $24 \mathrm{hr}$. The MMP-9, TIMP-1 and -2 mRNA levels were measured by RT-PCR. $\beta$-actin was used as an internal control.

기전은 MAP kinase가 알려져 있다[11, 15]. 따라서 이 실험에 서는 이들 작용기전을 확인하기 위해 모링가 뿌리 추출물에 의한 MAP kinase의 인산화 정도를 확인하였다. PMA 처리에 의해 증가된 ERK와 $\mathrm{p} 38, \mathrm{JNK}$ 의 인산화가 모링가 뿌리 추출물 에 농도의존적으로 $\mathrm{ERK}$ 와 $\mathrm{JNK}$ 의 인산화만이 저해되었다. 또 한 각 kinase total-form의 발현이 모링가 뿌리 추출물에 의해 저해되지 않아 모링가 뿌리 추출물이 kinase 활성 만을 저해 시킴을 알 수 있다(Fig. 5). 이 결과로 모링가 뿌리 추출물이 $\mathrm{ERK}$ 와 $\mathrm{JNK}$ 의 활성 저해를 통해 $\mathrm{MMP}-9$ 의 발현 및 활성을

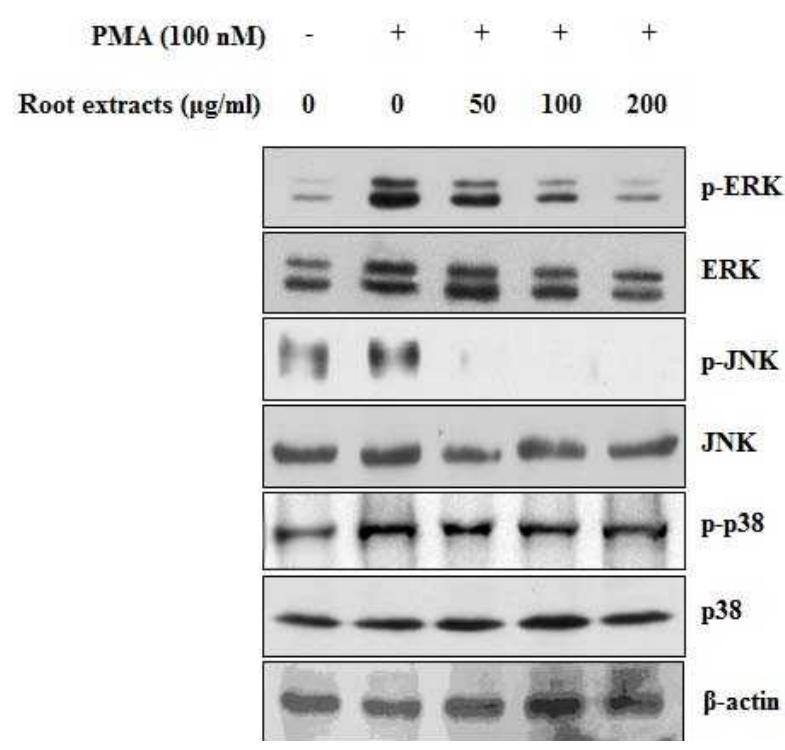

Fig. 5. Inhibitory effect of moringa root extract on phosphorylation of PMA-induced MAP kinase in MCF-7 cells. Moringa root extract was added into MCF-7 cells for $24 \mathrm{hr}$ before PMA stimulation and protein samples were harvested after PMA stimulation for $20 \mathrm{~min}$. The protein levels of MAP kinase were evaluated by Western blot analysis. $\beta$-actin was used as an internal control. 
조절하고 결과적으로 MCF-7의 암세포 침투를 저해시키는 것 으로 예상된다. 또한 MCF-7 세포에 PMA를 처리하여 MMP-9 활성 및 발현 조절기전을 확인한 다른 연구에서 MAP kinase 신호기전을 경유하여 전사인자인 AP-1 작용 조절을 통해 MMP-9의 활성 및 발현이 조절된다는 연구결과가 확인되어 [14] 모링가가 ERK의 인산화 조절을 통해 AP-1을 비롯한 하위 전사인자 발현을 조절하여 MMP-9의 발현을 조절할 것이라 예상된다.

최근 국외에서도 모링가 추출물을 이용한 연구가 진행 중이 며, 그 중에서도 모링가 잎과 뿌리를 이용한 연구가 활발히 수행되고 있다. 모링가 잎 추출물은 췌장암세포에서 NF-kB의 발현을 저해하여 화학요법의 세포독성을 증가시키고[5] 항산 화 효과를[22] 나타낼 뿐만 아니라 암세포 증식억제효과를[25] 나타낸다. 또한 모링가 뿌리 추출물은 궤양과 같은 위장질환 을 완화시키고[8] 항산화[3] 및 항염증 효과를 나타낸다. 그러 나 모링가 추출물을 이용하여 암세포 침투와 전이에 주요한 인자인 MMP-9에 대한 억제 효과는 아직 일반적으로 확인되 지 않아 이 연구결과의 의미가 더욱 중요할 것이라 판단된다.

\section{감사의 글}

이 연구는 2013년도 대구가톨릭대학교 의과학연구소 연구 비의 지원으로 이루어졌습니다. 그리고 모링가는 (주)유림물산 이태용 이사에게 제공받아 사용하였습니다.

\section{References}

1. Al-Said, M. S., Mothana, R. A., Al-Yahya, M. A., Al-Blowi, A. S., Al-Sohaibani, M., Ahmed, A. F. and Rafatullah, S. 2012. Edible oils for liver protection: hepatoprotective potentiality of Moringa oleifera seed oil against chemical-induced hepatitis in rats. J Food Sci 77, T124-130.

2. Anwar, F., Latif, S., Ashraf, M. and Gilani, A. H. 2007. Moringa oleifera: a food plant with multiple medicinal uses. Phytother Res 21, 17-25.

3. Atawodi, S. E., Atawodi, J. C., Idakwo, G. A., Pfundstein, B., Haubner, R., Wurtele, G., Bartsch, H. and Owen, R. W. 2010. Evaluation of the polyphenol content and antioxidant properties of methanol extracts of the leaves, stem, and root barks of Moringa oleifera Lam. J Med Food 13, 710-716.

4. Bendrik, C., Robertson, J., Gauldie, J. and Dabrosin, C. 2008. Gene transfer of matrix metalloproteinase- 9 induces tumor regression of breast cancer in vivo. Cancer Res 68, 3405-3412.

5. Berkovich, L., Earon, G., Ron, I., Rimmon, A., Vexler, A. and Lev-Ari, S. 2013. Moringa Oleifera aqueous leaf extract down-regulates nuclear factor-kappaB and increases cytotoxic effect of chemotherapy in pancreatic cancer cells. BMC Complement Altern Med 13, 212.

6. Bjorklund, M. and Koivunen, E. 2005. Gelatinase-mediated migration and invasion of cancer cells. Biochim Biophys Acta
1755, 37-69.

7. Cho, H. J., Kang, J. H., Kwak, J. Y., Lee, T. S., Lee, I. S., Park, N. G., Nakajima, H., Magae, J. and Chang, Y. C. 2007. Ascofuranone suppresses PMA-mediated matrix metalloproteinase-9 gene activation through the Ras/Raf/MEK/ ERK- and Ap1-dependent mechanisms. Carcinogenesis 28, 1104-1110.

8. Choudhary, M. K., Bodakhe, S. H. and Gupta, S. K. 2013. Assessment of the antiulcer potential of Moringa oleifera root-bark extract in rats. J Acupunct Meridian Stud 6, 214-220.

9. Fang, W., Li, H., Kong, L., Niu, G., Gao, Q., Zhou, K., Zheng, J. and $\mathrm{Wu}, \mathrm{B}$. 2003. Role of matrix metalloproteinases (MMPs) in tumor invasion and metastasis: serial studies on MMPs and TIMPs. Beijing Da Xue Xue Bao 35, 441-443.

10. Ghasi, S., Nwobodo, E. and Ofili, J. O. 2000. Hypocholesterolemic effects of crude extract of leaf of Moringa oleifera Lam in high-fat diet fed wistar rats. J Ethnopharmacol 69, 21-25.

11. Jung, J. S., Jung, K., Kim, D. H. and Kim, H. S. 2012. Selective inhibition of MMP-9 gene expression by mangiferin in PMA-stimulated human astroglioma cells: involvement of PI3K/Akt and MAPK signaling pathways. Pharmacol Res 66, 95-103.

12. Kato, Y., Yamashita, T. and Ishikawa, M. 2002. Relationship between expression of matrix metalloproteinase-2 and matrix metalloproteinase-9 and invasion ability of cervical cancer cells. Oncol Rep 9, 565-569.

13. Lee, H. J., Jeong, Y. J., Lee, T. S., Park, Y. Y., Chae, W. G., Chung, I. K., Chang, H. W., Kim, C. H., Choi, Y. H., Kim, W. J., Moon, S. K. and Chang, Y. C. 2013. Moringa Fruit Inhibits LPS-Induced NO / iNOS Expression through Suppressing the NF -kappa B Activation in RAW264.7 Cells. Am J Chin Med 41, 1109-1123.

14. Lee, S. O., Jeong, Y. J., Im, H. G., Kim, C. H., Chang, Y. C. and Lee, I. S. 2007. Silibinin suppresses PMA-induced MMP-9 expression by blocking the AP-1 activation via MAPK signaling pathways in MCF-7 human breast carcinoma cells. Biochem Biophys Res Commun 354, 165-171.

15. Ling, H., Zhang, Y., Ng, K. Y. and Chew, E. H. 2011. Pachymic acid impairs breast cancer cell invasion by suppressing nuclear factor-kappaB-dependent matrix metalloproteinase-9 expression. Breast Cancer Res Treat 126, 609-620.

16. Mahajan, S. G., Mali, R. G. and Mehta, A. A. 2007. Protective effect of ethanolic extract of seeds of Moringa oleifera Lam. against inflammation associated with development of arthritis in rats. J Immunotoxicol 4, 39-47.

17. Matsunaga, Y., Koda, M. and Murawaki, Y. 2004. Expression of matrix metalloproiteinases (MMPs) and tissue inhibitors of metalloproteinases (TIMPs) in hepatocellular carcinoma tissue, compared with the surrounding non-tumor tissue. Res. Commun. Mol Pathol Pharmacol 115-116, 143-150.

18. Okuda, T., Baes, A. U., Nishijima, W. and Okada, M. 2001. Coagulation mechanism of salt solution-extracted active component in Moringa oleifera seeds. Water Res 35, 830-834.

19. Okuda, T., Baes, A. U., Nishijima, W. and Okada, M. 2001. 
Isolation and characterization of coagulant extracted from Moringa oleifera seed by salt solution. Water Res 35, 405-410.

20. Ramirez, G., Hagood, J. S., Sanders, Y., Ramirez, R., Becerril, C., Segura, L., Barrera, L., Selman, M. and Pardo, A. 2011. Absence of Thy-1 results in TGF-beta induced MMP-9 expression and confers a profibrotic phenotype to human lung fibroblasts. Lab Invest 91, 1206-1218.

21. Roomi, M. W., Monterrey, J. C., Kalinovsky, T., Rath, M. and Niedzwiecki, A. 2009. Patterns of MMP-2 and MMP-9 expression in human cancer cell lines. Oncol Rep 21, 1323-1333.

22. Siddhuraju, P. and Becker, K. 2003. Antioxidant properties of various solvent extracts of total phenolic constituents from three different agroclimatic origins of drumstick tree (Moringa oleifera Lam.) leaves. J Agric Food Chem 51, 2144-2155.

23. Soreide, K., Janssen, E. A., Korner, H. and Baak, J. P. 2006. Trypsin in colorectal cancer: molecular biological mechanisms of proliferation, invasion, and metastasis. J Pathd 209, 147-156.

24. Sreelatha, S., Jeyachitra, A. and Padma, P. R. 2011. Antiproliferation and induction of apoptosis by Moringa oleifera leaf extract on human cancer cells. Food Chem Toxicol 49, 1270-1275.

25. Tiloke, C., Phulukdaree, A. and Chuturgoon, A. A. 2013. The antiproliferative effect of Moringa oleifera crude aqueous leaf extract on cancerous human alveolar epithelial cells. BMC Complement Altern Med 13, 226.
26. van 't Veer, L. J., Dai, H., van de Vijver, M. J., He, Y. D., Hart, A. A., Mao, M., Peterse, H. L., van der Kooy, K., Marton, M. J., Witteveen, A. T., Schreiber, G. J., Kerkhoven, R. M., Roberts, C., Linsley, P. S., Bernards, R. and Friend, S. H. 2002. Gene expression profiling predicts clinical outcome of breast cancer. Nature 415, 530-536.

27. Visse, R. and Nagase, H. 2003. Matrix metalloproteinases and tissue inhibitors of metalloproteinases: structure, function, and biochemistry. Circ Res 92, 827-839.

28. Wu, Z. S., Wu, Q., Yang, J. H., Wang, H. Q., Ding, X. D., Yang, F. and $\mathrm{Xu}, \mathrm{X}$. C. 2008. Prognostic significance of MMP-9 and TIMP-1 serum and tissue expression in breast cancer. Int J Cancer 122, 2050-2056.

29. Yokota, H., Kumata, T., Taketaba, S., Kobayashi, T., Moue, H., Taniyama, H., Hirayama, K., Kagawa, Y., Itoh, N., Fujita, O., Nakade, T. and Yuasa, A. 2001. High expression of 92 $\mathrm{kDa}$ type IV collagenase (matrix metalloproteinase-9) in canine mammary adenocarcinoma. Biochim Biophys Acta 1568, 7-12.

30. Yoon, A. and Hurta, R. A. 2001. Insulin like growth factor-1 selectively regulates the expression of matrix metalloproteinase-2 in malignant H-ras transformed cells. Mol Cell Biochem 223, 1-6.

31. Youn, U. J., Nam, K. W., Kim, H. S., Choi, G., Jeong, W. S., Lee, M. Y. and Chae, S. 2011. 3-Deoxysappanchalcone inhibits tumor necrosis factor-alpha-induced matrix metalloproteinase-9 expression in human keratinocytes through activated protein-1 inhibition and nuclear factor-kappa B DNA binding activity. Biol Pharm Bull 34, 890-893.

\section{초록 : 유방암 세포주에서 PMA로 유도된 암세포 침투에 대한 모링가 뿌리 추출물의 억제효과 조현지 ${ }^{1,2} \cdot$ 장영채 ${ }^{1,2}$ * ( ${ }^{1}$ 대구가톨릭대학교 의용생체공학연구소, ${ }^{2}$ 대구가톨릭대학교 의과대학 의학과)}

여성에게 특히 높은 발병률을 보이는 유방암은 다양한 인자에 의해 암세포 침투와 전이가 발생한다. 그중에서 MMP-9은 유방암에서 높은 발현율을 나타내며, 유방암 세포의 침투와 전이에 주요하게 작용한다. MMP-9은 다양 한 성장인자와 사이토카인, $\mathrm{PMA}$ 등에 의해 발현이 유도되며 세포 내 자연적으로 발생된 내생적 억제인자인 TIMP-1과 -2에 의해 그 활성 및 발현이 조절된다. MMP-9의 활성 및 발현을 저해하기 위해 사용한 물질은 모링가 추출물로 모링가의 모든 부위가 다양한 질환을 치료하는 것으로 알려져 있다. 이 연구에서는 대표적으로 모링가 씨, 뿌리, 잎, 열매 추출물질을 이용하여 MMP-9의 활성억제 유무를 연구하였으며, MCF-7 세포에서 모링가 뿌리 추출물이 MMP-9을 가장 효과적으로 억제하였다. 또한 MDA-MB-231을 이용한 비교실험에서도 세포특이성 없이 MMP-9의 활성 및 발현이 모링가 뿌리 추출물에 의해 억제되었고 단백질과 mRNA 발현에서도 동일한 결과가 도출되었다. 뿐만 아니라 암세포 침투실험에서도 모링가 뿌리 추출물에 의해 암세포 침투가 $50 \%$ 이상 감소 되었 으나, TIMP-1과 -2 mRNA 발현은 모링가 뿌리 추출물에 의해 저해되지 않았으므로 모링가 뿌리 추출물이 MMP-9 활성 및 발현 저해를 통해 암세포 침투를 저해시키는 것으로 예상된다. 그리고 MMP-9 활성 및 발현 조절 기전을 확인하기 위해 MAP kinase의 인산화를 확인한 실험에서 모링가 뿌리 추출물이 ERK와 JNK의 인산화를 억제시킴을 확인하였다. 결론적으로 이 실험을 통해 모링가 추출물 중 뿌리 추출물이 MMP-9 활성 및 발현저해에 가장 효과적이며, $\mathrm{ERK}$ 와 JNK의 인산화 조절을 통해 MMP-9의 활성 및 발현을 직접적으로 조절함을 확인할 수 있었다. 